\title{
Change in Atlantic cod migrations and adaptability of early land-based fishers to severe climate variation in the North Atlantic
}

\author{
Ragnar Edvardsson ${ }^{\mathrm{a} *}$, William P. Patterson ${ }^{\mathrm{b}}$, Hlynur Bárðarson ${ }^{\mathrm{c}}$, Sandra Timsic $^{\mathrm{b}}$, Guðbjörg Ásta Ólafsdóttir ${ }^{\mathrm{a}}$ \\ ${ }^{a}$ University of Iceland, Research Centre of the Westfjords, Hafnargata 9b, IS415 Bolungarvík, Iceland \\ ${ }^{\mathrm{b}}$ Department of Geological Sciences, University of Saskatchewan, Saskatoon, Saskatchewan S7N 5E2, Canada \\ ${ }^{c}$ Marine and Freshwater Research Institute, Skúlagata 4, IS121 Reykjavik, Iceland \\ *Corresponding author e-mail address: red@hi.is
}

(Received April 3, 2018; AccePted November 25, 2018)

\begin{abstract}
We use biochemical, biological, archaeological, and historical analysis to examine relationships between Atlantic cod migration, sea temperature, and shifts in the distribution and occupancy of historical fishing sites in Iceland during the last millennium. Results support the hypothesis that the cooling climate of the North Atlantic during the period commonly referred to as the Little Ice Age coincided with changes in Atlantic cod migration patterns. Historical analysis shows a concomitant increase in reports of worsening Atlantic cod fishing and a severe decrease in domestic fishing, particularly in north Iceland. We conclude that Atlantic cod fisheries in Iceland originally thrived because of the proximity to cod migration routes. However, despite the mobility of local fishers, fluctuations in fish migrations, coupled with a harsher climate and increased competition for fishing grounds, resulted in a stagnation that lasted until the eventual modernization of the fishery in the mid-nineteenth century.
\end{abstract}

Keywords: Atlantic cod; Fish migrations; Historical fishing; Subarctic seas; Little Ice Age; Ecological baseline; Cultural adaptation

\section{INTROUCTION}

Archaeological excavations of early commercial fishing sites can provide information on past economies, and the zooarchaeological material recovered at these sites allows biochemical and biological investigations on historical marine ecology (Hambrecht et al., 2018). There are many well-preserved historical fishing sites in Iceland, and the island's geographical position, on the interface between temperate and subarctic seas, makes zooarchaeological investigations on these sites particularly suitable to examine the ecological effects of past climate fluctuations in the North Atlantic. Opposing oceanic fronts, the warm North Atlantic Current and the cold Arctic East Greenland and East Iceland Currents, result in substantial differences in sea temperature and concomitant variation in the marine environment across the island's latitudinal gradient (Ingólfsson, 2006; Astthorsson et al., 2007).

Cite this article: Edvardsson, R., Patterson, W. P., Bárðarson, H., Timsic, S., Ólafsdóttir, G. Á. 2022. Change in Atlantic cod migrations and adaptability of early land-based fishers to severe climate variation in the North Atlantic. Quaternary Research 108, 81-91. https://doi.org/ 10.1017/qua.2018.147
The commercialization of Atlantic cod (Gadus morhua) fisheries commenced in the North Sea in the eleventh to thirteenth centuries, expanding to the North Atlantic and then to the Newfoundland banks (Starkey et al., 2000; Barrett et al., 2001; Barrett et al., 2004b, 2011). The Atlantic cod's life history as a highly fecund, long-growing, top predator with a broad natural distribution set the scene for commercial exploitation at that scale. However, Atlantic cod distribution is sensitive to variation in water temperatures. Fisheries research has demonstrated that Atlantic cod feeding migrations, spawning distributions, and larval transport are determined by climate and oceanographic factors (Drinkwater, 2005). The Icelandic cod stock, for example, exhibited varying migration and foraging ranges in response to sea temperature changes (Astthórsson et al., 2007). However, groups or populations within cod stocks commonly display varying migratory tendencies (Campana and Casselman, 1993; Pálsson and Thorsteinsson, 2003; Robichaud and Rose, 2004; Neat et al., 2006; Thorsteinsson et al., 2012). Some populations complete their life cycle in nearshore waters, whereas others engage in long-range feeding migrations, only returning to coastal waters to spawn. The different Atlantic cod migratory 
ecotypes may respond differently to fishing pressure and climate forcing (Árnason et al., 2009; Jakobsdóttir et al., 2011).

Biochemical and biological analysis of zooarchaeological material has been increasingly used to estimate ecological variables of past animal populations, for example, population genetic analysis (Ólafsdóttir et al., 2014; Star et al., 2017), stable isotope reconstructions of historical ecology (Emslie and Patterson, 2007; Misarti et al., 2009; Clark et al., 2017), and estimates of growth and age structure using otoliths (Van Neer et al., 1999, 2002; Geffen et al., 2011; Ólafsdóttir et al., 2017). In particular, $\delta^{13} \mathrm{C}$ values of marine organisms are known to reflect sea temperature, as primary production is directly affected by lower temperatures, and this is carried to higher trophic levels (Fry, 1988). Slower growth and metabolic rates of ectotherms will also result in more variable $\delta^{13} \mathrm{C}$ values (Gorokhova, 2017), perhaps augmenting the effects of sea temperature. Otoliths, calcified structures of the inner ear of fish (Reibisch, 1899), are occasionally recovered in archaeological excavations. Otolith annuli record the annual growth of individual fish and are often used in fish biology as measures of fish growth (Campana, 2005) and less commonly in zooarchaeology (Van Neer et al., 1999, 2002; Geffen et al., 2011; Disspain, 2016; Ólafsdóttir et al., 2017). Fish growth is not only reflected in annulus size but also in otolith shape (Campana and Casselman, 1993), and otolith shape analysis is now commonly used to analyze fish ecology and environmental conditions and, in turn, to assign individual fish to stocks or subpopulations (Campana and Casselman, 1993; Jónsdóttir et al., 2006). In both Iceland and Norway, otolith shape variation can be used to distinguish migratory and coastal Atlantic cod ecotypes (Stransky et al., 2008; Geffen et al., 2011; Bardarson et al., 2017).

Changes in the distribution and migrations of cod around Iceland in the twentieth century support predictions of similar patterns in historical times. Such climate-driven changes in migration may result in overfishing (as migratory stocks boom) and subsequent crashes in fisheries. Centennial records of climate-driven migratory shifts could therefore provide a valuable baseline for conservation and management. The substantial cooling of the North Atlantic, succeeding the Medieval Warm Period and cumulating in severe cold periods in the sixteenth to nineteenth centuries, the Little Ice Age (Ogilvie and Jónsson, 2001), may have specifically resulted in changes in migrations and distributions of marine populations. Previous studies of archaeological Atlantic cod bones, for example, support population changes (Ólafsdóttir et al., 2014) and changes in fish growth (Geffen et al., 2011; Ólafsdóttir et al., 2017) in the sixteenth to seventeenth centuries. In the current paper, we examine parallels in multidisciplinary proxies reflecting migration or distribution shifts in Atlantic cod, sea temperature, and concomitant shifts in the distribution and occupancy of historical fishing sites. We use biochemical, biological, archaeological, and historical analysis spanning the time since the onset of cod fisheries in Iceland ca. AD 1000 to modern times. We expect periods of low sea temperature, and the concomitant ecological effects of nearshore sea ice, lower primary production, and less prey availability, to be reflected in lower carbon stable isotope values $\left(\delta^{13} \mathrm{C}\right)$ of Atlantic cod and lower frequency of migratory cod in the historical catch. Moreover, we expect the occupancy of historical fishing sites to reflect our prediction of environmentally forced shifts in cod availability, with fishing sites shifting south during cold periods and establishment of northern fishing sites during warmer periods.

\section{The history and archaeology of the Icelandic subarctic fisheries}

Iceland was settled in the late ninth century by settlers who were predominantly from Scandinavia but also from the British Isles. The settlement of the island was completed by the late tenth to early eleventh centuries (Vésteinsson, 1998, 2000; McGovern et al., 2007). During early settlement the economy was based on agriculture, that is, animal husbandry and pastoralism, and agriculture remained the main source of income until the early thirteenth century (McGovern et al., 2007; Edvardsson, 2010). Archaeological evidence suggests that in the eleventh to thirteenth centuries, agriculture was encumbered by soil erosion (Pórarinsson, 1961; Dugmore and Buckland, 1991; Ólafsdóttir and Guðmundsson, 2002; Dugmore et al., 2005; McGovern et al., 2007), and decreasing demand for agricultural products in Europe caused prices to drop (Porláksson, 1992; Porsteinsson, 1995), which caused a decline in the Icelandic economy.

Historical and archaeological evidence suggests that subarctic fisheries in Iceland were established concurrent with the settlement of the island in the tenth century. During early settlement, most coastal farmers fished from their farms, and fishing was primarily aimed at a domestic market (Bjarnason, 1883; McGovern et al., 2007; Edvardsson, 2010). The thirteenth century saw a steady increase in the demand for dried fish, that is, Atlantic cod, compelling European merchants to seek new sources in the North Atlantic, especially Norway, Iceland, and the Faroe Islands. In turn, fish prices increased rapidly, and the economy of Iceland became more reliant on fishing (Baasch, 1889; Porsteinsson, 1995; Starkey et al., 2000; Barret et al., 2004a; Gardiner, 2016; Vésteinsson, 2016). The early thirteenth-century expansion in commercial fishing in Iceland is recorded in the historical and archaeological record, and many new commercial fisheries were established during this period (Edvardsson, 2010). The Icelandic commercial cod fisheries thrived in the period between AD 1250 and AD 1550, as there was a steady European demand for dried fish, especially by German and English merchants (Heath, 1968; Porsteinsson, 1995; Starkey et al., 2000).

Atlantic cod fisheries developed primarily off the west coast of Iceland, with the primary fishing grounds located off the Reykjanes and Snæfellsnes peninsulas and in the Westfjords (Fig. 1). The historical record categorizes four types of fisheries in Iceland, that is, home base (Icelandic: heimver), camp (Icelandic: viðlegurver), mixed base (Icelandic: blandað ver), and outlying base (Icelandic: útver) (Kristjánsson, 1980). Home base was the place from which a fisher-farmer set out during fishing trips and was used generally only by himself and his farmhands. Camp is a place 

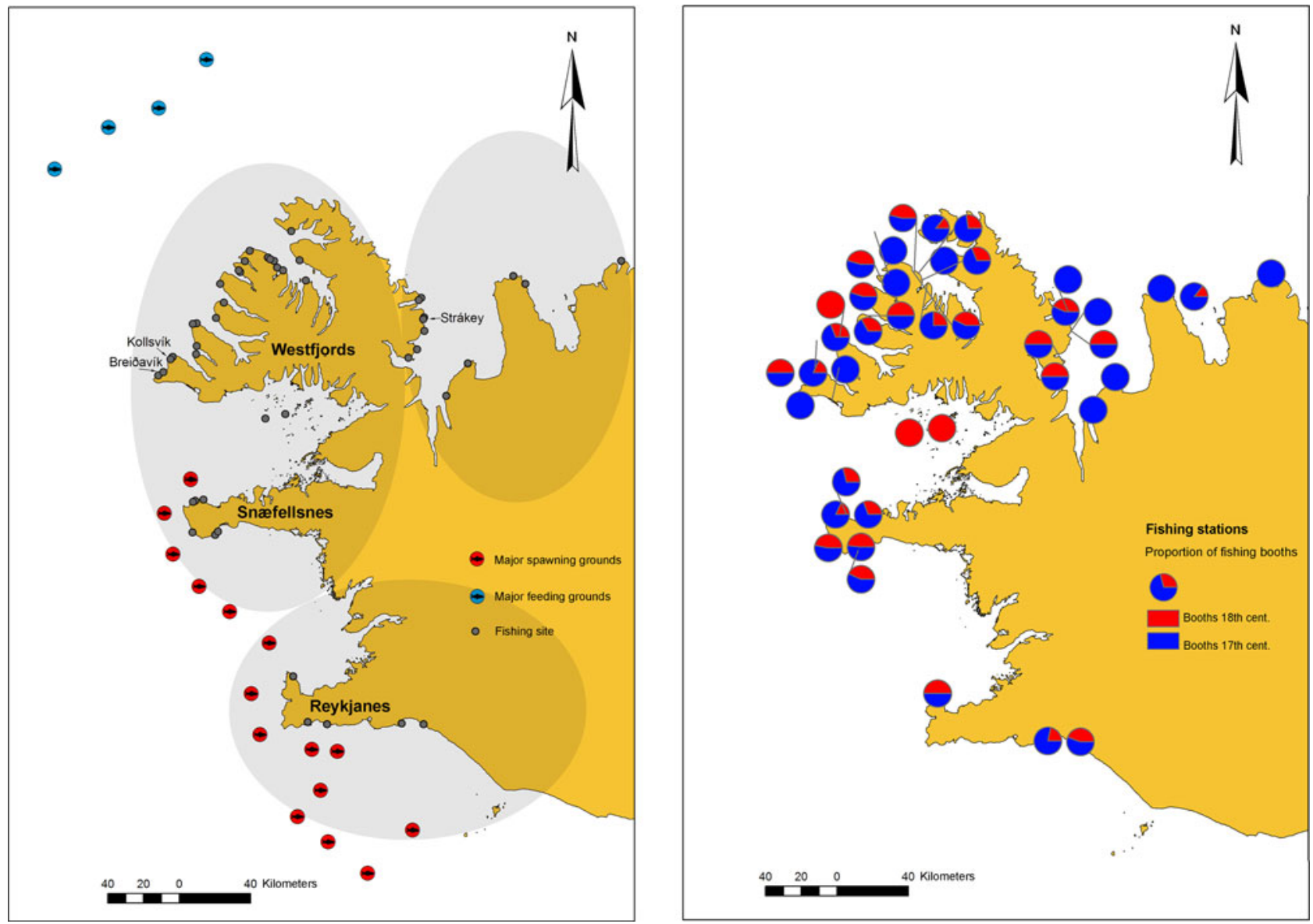

Figure 1. Left, A map showing western Iceland and the major spawning (red circles) and feeding (blue circles) grounds of Atlantic cod (note that the map excludes smaller spawning grounds found along the coast and does not depict variation in feeding grounds). Historical fishing sites are marked (gray circles), specifying the archaeological sample sites of Breiðavík (BRV), Kollsvík (KOV), and Strákey (STR). Right, A map showing changes in fishing-site occupancy between the seventeenth and eighteenth centuries as described in the land registry of Magnússon and Vídalín (1940).

where many farmers from the region used a home base of a particular farm during the fishing season. Outlying base is a particular place on one's farmland, not close to the farm itself, where fishermen set out on their fishing trips during the fishing season. Mixed base is a fishing station that seems to be a mixture of the other three types of fishing sites. Archaeological research has demonstrated that the two latter types generally display preserved structures, but the former do not necessarily preserve any remaining structures (Edvardsson, 2010). Commercial fishing was mostly carried out from outlying and mixed bases, with excavations indicating that Atlantic cod were the primary targeted fish, representing $80 \%-90 \%$ of the catch landed. Other species, such as saithe (Pollachius virens), haddock (Melanogrammus aeglefinus), redfish (Sebastes sp.), Atlantic wolffish (Anarhichas lupus), and Atlantic halibut (Hippoglossus hippoglossus), were also targeted, primarily for domestic consumption (Amorosi et al., 1994; Amundsen et al., 2005; Harrison, 2014). The typical commercial fishing station consisted of fishing booths, small oval or rectangular structures made of turf where fishermen lived during the fishing season, boat landings, boathouses, winches, fish-drying platforms, and sheds. The number of structures at each site varies between regions, with the greatest number occurring on the west coast and fewer in the north and on the east coast. The general layout remained invariant, although fishing booths tend to grow larger over time (Edvardsson, 2010). The most common boat was a small open boat, powered by oars and sails, with a crew of 7-12 men; no decked vessels were used by Icelanders until the late eighteenth and early nineteenth centuries (Kristjánsson, 1980).

The position and occupancy of historical fishing stations, interpreted in light of modern-day knowledge of Atlantic cod ecology (Sólmundsson et al., 2017), suggest that the stations were strategically positioned to target Atlantic cod migrations, specifically feeding migrations in the north and northwest and spawning migrations, and perhaps spawning sites, in the west and southwest.

\section{METHODS}

\section{Archaeological data}

Archaeological excavations were carried out at the fishing sites of Breiðavík (BRV) and Kollsvík (KOV) on the southern 
part of the Westfjords (Fig. 1). Trenches were excavated into midden deposits, and the single context method was employed. All contexts were cleaned, photographed, planned, and finally removed. The minimum size of each trench was $1 \mathrm{~m} \times 1 \mathrm{~m}$, although some were slightly larger. All excavated contexts were dry-sieved with a $5 \mathrm{~mm}$ mesh, and all finds were removed and analyzed. Fish bones were removed from the bone assemblage and analyzed separately. Terrestrial herbivore bones, when present, were used to date the deposits by ${ }^{14} \mathrm{C}$ dating (Scottish Universities Environmental Research Centre).

A subset of the Atlantic cod vertebrae and all whole Atlantic cod otoliths were used for subsequent analysis. Statistical analysis of the zooarchaeological data was accomplished by pooling material into groups (each approximately representing one century) using ${ }^{14} \mathrm{C}$ dates, finds, and/or stratigraphic sequence information (Table 1). In addition to the material excavated at BRV and KOV, 14 otoliths from the fishing site at Strákey (STR; Fig. 1) were included in the analysis. These otoliths were removed from contexts dated by finds to the sixteenth century (Edvardsson, 2018).

\section{Stable isotope analysis}

Loose sediment was removed from vertebrae by brush, while fine cleaning was performed in an ultrasonic bath (model 550D, VWR), with samples immersed in deionized water for 4 minutes. Samples were oven-dried overnight at $60^{\circ} \mathrm{C}$. Dry samples were powdered in a swing mill. Collagen was extracted according to Leyden et al. (2006). Stable isotope values were obtained using a Thermo Finnigan Flash 1112 EA coupled to a Thermo Finnigan Delta Plus XL via a Conflo III interface. Carbon isotope ratios were corrected for ${ }^{17} \mathrm{O}$ contribution using the Craig correction and reported in per mil notation relative to the Vienna PeeDee Belemnite scale (VPDB). Nitrogen isotope ratios, used for quality control of the $\delta^{13} \mathrm{C}$ values, were reported in per mil notation relative to the Atmospheric Air Reference Scale (AIR). Carbon data were calibrated against the international standards L-SVEC $\left(\delta^{13} \mathrm{C}=-46.6 \%\right.$ ovPDB $)$ and IAEA-CH6 $\left(\delta^{13} \mathrm{C}=\right.$ $\left.-10.45 \%{ }_{\mathrm{VPDB}}\right)$. Nitrogen data were calibrated against the international standards USGS-25 $\left(\delta^{15} \mathrm{~N}=-30.4 \%_{\mathrm{AIR}}\right)$ and IAEA-305A $\left(\delta^{15} \mathrm{~N}=39.8 \%\right.$ oAIR $\left._{\text {A }}\right)$.

Samples were tested for collagen quality by confirming that their atomic $\mathrm{C} / \mathrm{N}$ ratio fell within the range of 2.9 and 3.6, resulting in $81 \delta^{13} \mathrm{C}$ values used for analysis (Supplementary Table 1).

\section{Otolith shape analysis}

One hundred sixty-four otoliths could be used for shape analysis (Table 1). All otoliths used were well preserved, with no breaks or wear that could affect shape determination. Shape analysis was done "blinded," that is, without information on ${ }^{14} \mathrm{C}$ dating or stratigraphic sequence.

High-contrast digital images were captured using a Leica IC80 HD (Digital Camera Module by Leica Microsystems) under a stereomicroscope at $10 \times$ magnification. Background lighting was used, resulting in dark two-dimensional otolith images with bright backgrounds. The otoliths were orientated such that the rostrum was placed in the lower left corner for otoliths from the right side of the fish; for otoliths from the left side the image was flipped. The outlines were automatically traced using a black-and-white pixel gradient. Fourier descriptors (FD) were obtained from the outlines using the 'shapeR' (Libungan and Pálsson, 2015) and 'Ime4' packages in R (Bates et al., 2015). The otolith images are normalized in regard to the size and orientation of the otolith by fixing the first FD to 1 and the second FD to 0, respectively.

Bardarson et al. (2017) showed that otolith shape correlated with migration patterns of Atlantic cod that had been tagged with data storage tags. Specifically, otoliths from migratory cod are more streamlined or elongated compared with the more deeply shaped otoliths of the coastal ecotype (Fig. 2). Following Bardarson et al. (2017), FD3 and FD8 and three shape variables, roundness, aspect ratio, and circularity, were used as factors in a generalized linear model (GLM) to estimate the migratory value (ranging from 0 to 1) of each archaeological otolith. Values from 0 to 0.50 indicate Atlantic cod with intermediate to high migratory tendency, and values from 0.50 to 1 indicate cod with intermediate to high resident (coastal) tendency. This GLM has previously been selected as the best model for classification of otoliths to migratory ecotypes, correctly predicting the migratory ecotypes of Atlantic cod around Iceland in more than $90 \%$ of cases (Bardarson et al., 2017). See Supplementary Table 2 for specifics of assignment.

\section{Historical analysis}

To get estimates of fishing site occupancy (Fig. 1), we used the land registry of Árni Magnússon and Páll Vídalín (1940). This land registry, which was intended for tax purposes, was compiled in the period AD 1702-1712 by the order of the Danish king and gives the value of each individual farm and rent, the number of domestic animals, farm benefits, and other pertinent information. It contains descriptions of fishing stations, including the number of boats and booths occupied in the early eighteenth century and the number of booths and boats occupied in the seventeenth century.

Historical references to cod fishing were extracted from the Icelandic Annals (Íslenskir Annálar sive Annales Islandici ab anno Christi ad annum 1400 and Íslenskir Annálar 14001800, Annales Islandici Saeculorum Posteriorum). The Icelandic Annals are commonly designated as ancient annals, covering the years $\mathrm{AD} 803$ to $\mathrm{AD} 1430$, and later annals, covering AD 1430 to $A D$ 1800. The ancient annals are based upon secondary written sources, whereas the more recent annals, especially in the period AD 1600-1800, were written exclusively about contemporary events. The annals cover different topics of current interest, including deaths of eminent people, natural disasters, weather, political events, and fishing. The annals, therefore, offer historical documentation of economic and natural events that affected the lives and 
Table 1. Summary information of the zooarchaeological material used for analysis.

\begin{tabular}{|c|c|c|c|c|c|c|c|}
\hline Temporal group & Dating & ${ }^{14} \mathrm{C}$ reference & $\begin{array}{l}\text { Site.year } \\
\text { [context] }^{\mathrm{a}}\end{array}$ & $\begin{array}{l}\text { No. coastal } \\
\text { otoliths }\end{array}$ & $\begin{array}{l}\text { No. migratory } \\
\text { otoliths }\end{array}$ & $\begin{array}{l}\text { No. } \\
\delta^{13} \mathrm{C}\end{array}$ & $\begin{array}{l}\text { Mean } \\
\delta^{13} \mathrm{C} \\
\end{array}$ \\
\hline Tenth century & $980 \pm 30{ }^{14} \mathrm{C} \mathrm{BP}$ & SUERC-65279 (GU39768) & BRV.15 [8] & 4 & 8 & 19 & -13.5 \\
\hline \multirow[t]{2}{*}{ Fourteenth century } & Context $(\leq 1410)$ & & BRV.15 [17] & 11 & 48 & 3 & -12.3 \\
\hline & $540 \pm 30{ }^{14} \mathrm{C}$ yr BP & SUERC-65278 (GU39767) & BRV.15 [16] & & & 16 & -12.1 \\
\hline \multirow[t]{4}{*}{ Sixteenth century } & Finds to sixteenth century & & STR.17 & 5 & 19 & & - \\
\hline & $396 \pm 30{ }^{14} \mathrm{C}$ yr BP & SUERC-45504 (GU29894R) & BRV.12 [5] & & & 6 & -13.1 \\
\hline & Context (1410-1649) & & BRV.15 [15] & & & & - \\
\hline & Context (1410-1649) & & BRV.15 [14] & & & 5 & -12.1 \\
\hline \multirow{4}{*}{ Seventeenth century } & $313 \pm 32{ }^{14} \mathrm{C}$ yr BP & SUERC-65281 (GU39770) & BRV.15 [7] & 15 & 27 & 4 & -15.2 \\
\hline & Finds to seventeenth century & & BRV.15 [13] & & & & - \\
\hline & Context (1637-1680) & & BRV.15 [6] & & & 11 & -13.2 \\
\hline & $270 \pm 32{ }^{14} \mathrm{C}$ yr BP & SUERC-45503 (GU29890R) & BRV.15 [5] & & & 1 & -20.6 \\
\hline \multirow[t]{3}{*}{ Eighteenth century } & $165 \pm 30{ }^{14} \mathrm{C}$ yr BP & SUERC-65281 (GU39770) & BRV.15 [4] & 7 & 2 & & - \\
\hline & $155 \pm 28{ }^{14} \mathrm{C}$ yr BP & SUERC-45204 (GU29889) & KOV.12 [2] & & & 2 & -13.3 \\
\hline & $130 \pm 32{ }^{14} \mathrm{C}$ yr BP & SUERC-65280 (GU39769) & BRV.15 [3] & & & 7 & -11.7 \\
\hline \multirow[t]{2}{*}{ Nineteenth century } & Finds to nineteenth century & & BRV.15 [12] & 7 & 11 & 5 & -13 \\
\hline & Context $(>1890)$ & & BRV.15 [1] & & & 2 & -19.1 \\
\hline
\end{tabular}

a "Site.year [context]" refers to excavation site, year excavated, and archaeological context (e.g., BRV015[8] = Breiðavík, 2015, context 8).

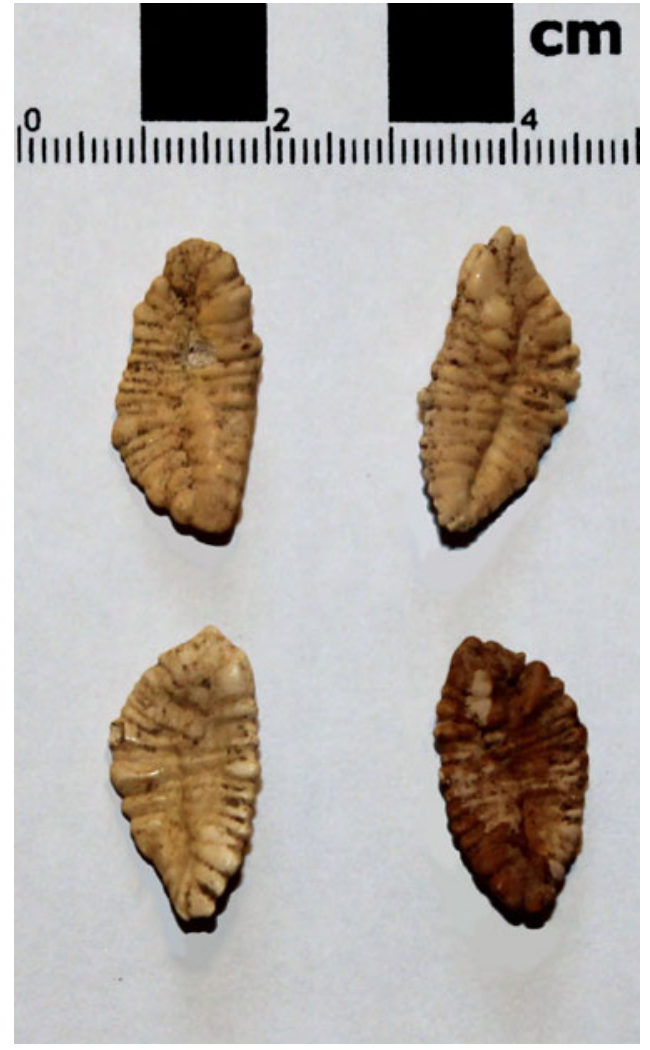

Figure 2. Examples of the Atlantic cod otoliths used in the current study. The top two otoliths represent the migratory ecotype, and the lower two otoliths the coastal ecotype.

livelihood of local people. All references to Atlantic cod fishing were extracted. For a comparable data set on fishing (although not including weather or sea ice) in AD 18001878, we used the published compilation of Bjarnason
(1883). The references were assigned to a region (north, west, or south) following the designation of regions shown in Figure 1, and all references to bad weather or sea ice hindering fishing were noted.

\section{Statistical analysis}

To test whether the Atlantic cod vertebrae $\delta^{13} \mathrm{C}$ values (reflecting lifetime temperature exposure) varied between centuries, we used a Kruskal-Wallis test with post hoc Mann-Whitney $U$-tests with Benjamini-Hochberg correction for multiple comparisons. To test whether the proportion of migratory-type otoliths differed between centuries, we used a two proportions $z$-test.

To examine variation in the number of references to good, average, or bad fishing between centuries and regions we used a GLM (general linear model). The number of references formed the dependent variable, with region, type of references (good, bad, average), and temporal group (century) being the fixed effects, with interaction between both the type of effect and temporal group and region and temporal groups (the size of the data set did not allow a model that estimated all interaction effects). All statistical analysis was done in R v. 3.4.2 (R Core Team, 2017) using RStudio v. 1.0.153 (RStudio Team, 2015).

\section{RESULTS}

\section{Stable isotope analysis}

The Atlantic cod vertebrae $\delta^{13} \mathrm{C}$ values varied between $-10.0 \%$ and $-20.6 \%$ and had a mean of $-13.1 \%$. These values are akin to previously published values from Atlantic 
cod zooarchaeological material (Orton et al., 2011). There was significant variation in $\delta^{13} \mathrm{C}$ values between centuries (Kruskal-Wallis $\chi^{2}=22.10, \mathrm{df}=5, P<0.001$ ) (Fig. 3). Post hoc Mann-Whitney $U$-tests with Benjamini-Hochberg correction showed that the $\delta^{13} \mathrm{C}$ values were significantly lower in the tenth, seventeenth, and nineteenth centuries, reflecting cooler sea temperatures and/or lower primary production in the cod environment, than in the fourteenth century $(P<0.01)$.

\section{Otolith shape analysis}

Most of the archaeological Atlantic cod otoliths were assigned to the otolith shape characteristic of the modern-day migratory cod type (Table 1). Migratory otolith shape was predominant in the sample until the seventeenth century (Fig. 3, Table 1). The percentage of otoliths assigned to the migratory otolith shape was significantly lower in the seventeenth, eighteenth, and nineteenth centuries $(36 \%, 78 \%$, and $40 \%$, respectively) than in the fourteenth and sixteenth centuries $(19 \%$ and $21 \%$, respectively) $(z=2.88, \mathrm{df}=1, P<0.01)$, suggesting that at the peak of historical fisheries, migratory cod was much more prevalent in the catch. The percent of migratory otoliths in the tenth century $(33 \%)$ did not differ significantly from other periods.

\section{Historical analysis}

Data from the eighteenth-century land registry clearly signal a decline in the number of fishing booths, particularly in the north, between the seventeenth and eighteenth centuries (Fig. 1). From a total of 404 general references to Atlantic cod fishing in the Annals, 232 could be assigned to either the northern, western, or southern regions (Table 2). The results from the GLM show that references to fishing were more frequent in west Iceland than in north Iceland and that references are most frequent in the eighteenth century (Table 3). References to bad fishing were least likely to refer to west Iceland, and references to good fishing increased in the nineteenth century (Table 2). A total of 16 references were made to sea ice or bad weather hindering cod fishing, most commonly in the eighteenth century (Fig. 3).

\section{DISCUSSION}

Carbon stable isotope values $\left(\delta^{13} \mathrm{C}\right)$ reflect rates of primary production and photosynthetic fractionation (Fry, 1988) and are generally lower in poikilotherms inhabiting colder waters (Ramos and González-Solís, 2012). Carbon stable isotope values also correlate to metabolic rates in poikilotherms (Wurster and Patterson, 2003; Wurster et al., 2005) and may reflect growth rate and food source limitation (Gorokhova, 2017). The current results of lower $\delta^{13} \mathrm{C}$ values in the seventeenth and nineteenth centuries (Fig. 3) are consistent with either decreased sea temperature and slower growth (related to lower temperature decreasing metabolism) or, alternatively, shifts in Atlantic cod migration to colder water that would result in the same effect. The lower $\delta^{13} \mathrm{C}$ values coincide with recorded cold periods and harsh climate conditions in the North Atlantic (Ogilvie and Jónsdóttir, 2000; Dahl-Jensen et al., 1998) (Fig. 3), supporting a hypothesis of local cooling.

Other variations in the current $\delta^{13} \mathrm{C}$ data, for example, the relatively low values in the tenth century and high values in the eighteenth century, may reflect fluctuations rather than consistent cooling during the Little Ice Age (Jiang et al., 2005; Patterson et al., 2010). Studies of seasonality as well as winter and summer sea-surface temperatures on the Iceland shelf suggest earlier and more severe fluctuations of summer temperature at the onset of the Little Ice Age (Jiang et al., 2005; Patterson et al., 2010). In particular the summer seasurface temperatures of the North Iceland shelfs appear to coincide well with the current $\delta^{13} \mathrm{C}$ data (Fig. 3). Moreover, the $\delta^{13} \mathrm{C}$ data represent lifetime values of a highly mobile species. Migratory cod engage in northern feeding migrations and are exposed to colder waters than coastal cod (Pálsson and Thorsteinsson, 2003; Thorsteinsson et al., 2012). However, an alternative hypothesis, that the lower $\delta^{13} \mathrm{C}$ values represent not lower local sea temperatures but increases in migration and migratory cod in the catch, is contradicted by the observed lower frequency of migratory-type otoliths in seventeenth to nineteenth-century catches (Fig. 3).

Both migratory and coastal populations of Atlantic cod are common at the northern distribution range of the cod distribution, such as around Iceland (Robichaud and Rose, 2004). The archaeological otolith analysis showed that migratorytype otoliths in the catch were most frequent in the fourteenth to sixteenth centuries, at the peak of land-based Atlantic cod fisheries in Iceland (Fig. 3). The lower proportion of migratory cod to coastal cod in the catch after AD 1600 may reflect three nonexclusive mechanisms: (1) population changes, for example, lower frequency of migratory cod in the Atlantic cod stock; (2) climate effects, such as climate forcing of Atlantic cod migration patterns; or (3) weather conditions that hindered fishers from targeting the cod migrations but had no effect on migration patterns or population composition. Certainly, historical references suggest that conditions for fishing were often unfavorable during the eighteenth and early nineteenth centuries and that sea ice was common in coastal regions (Fig. 3). However, the north Iceland Atlantic cod fisheries deteriorated before any increase in references to weather detrimental to fishing (Fig. 3). Modern-day fisheries research has documented reoccurring shifts in the migration patterns of fish species in Icelandic waters in response to temperature change (reviewed in Valdimarsson et al., 2012). Feeding migrations may be particularly flexible, as the Atlantic cod responds to changes in both sea temperature and prey distribution; this happened during a warm period of the twentieth century when foraging Atlantic cod followed the Arctic capelin north (Astthorsson et al., 2007). Shifts in feeding migrations may well explain the archaeological and historical data presented in the current paper, that is, during periods of significant cooling, the Atlantic cod foraging grounds north of Iceland were no longer reliable fishing grounds. On the other hand, the large spawning grounds and associated 


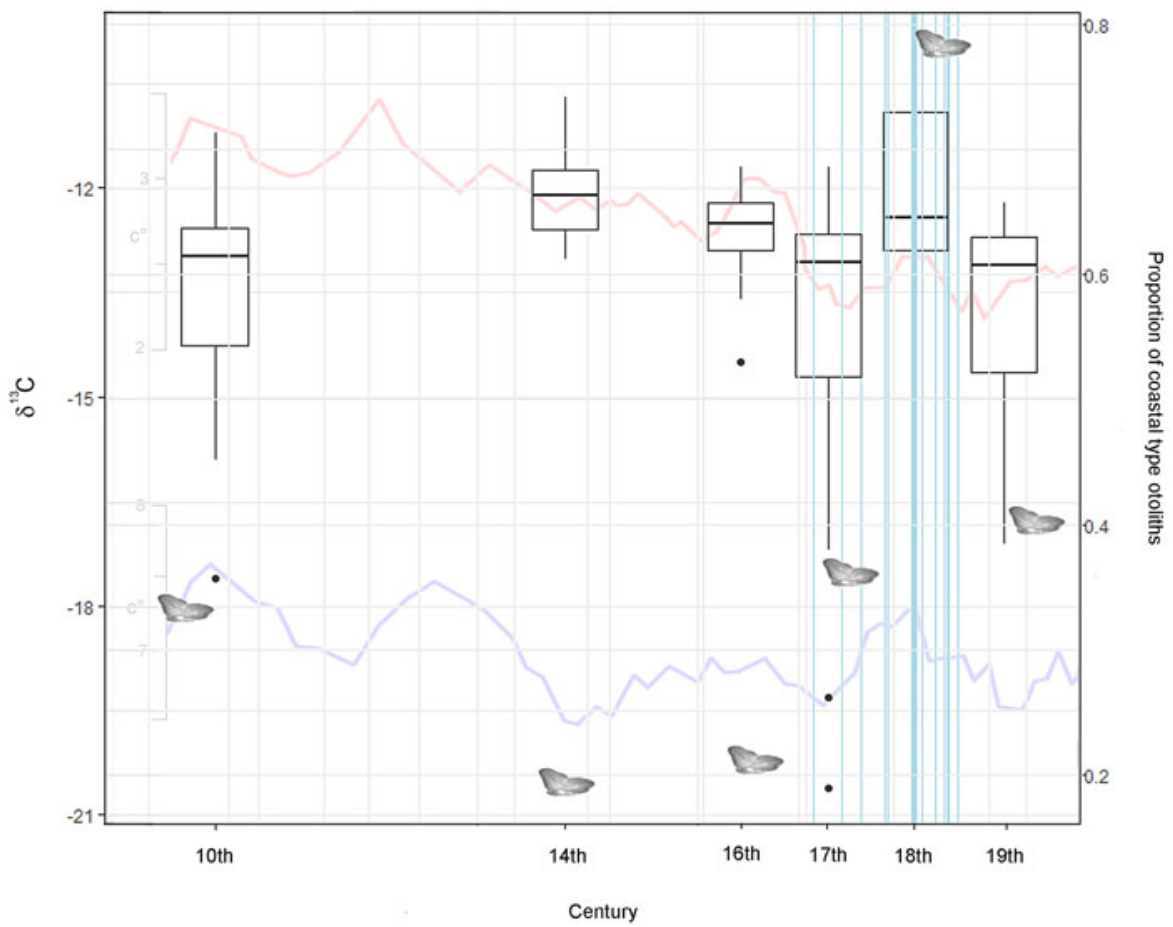

Figure 3. The box plots show $\delta^{13} \mathrm{C}$ values from Atlantic cod vertebrae in the historical catch in each of the temporal groups, specifically the median (horizontal black line) and first (box) and third (whiskers) quartiles. Outliers are presented as black circles. The $\delta^{13} \mathrm{C}$ scale is on left $\mathrm{y}$-axis. The frequency of coastal otoliths in the historical catch is depicted as figures of otoliths, with the scale on the right $y$-axis. Reference to sea ice or bad weather hindering fishing in the Icelandic annals (before AD 1800) are depicted as light blue vertical lines. Finally, reconstructed summer (blue line) and winter (red line) sea-surface temperatures off North Iceland (from Jiang et al., 2005) are shown in the background.

spawning migrations in the west and southwest (Sólmundsson et al., 2017) were more consistently favorable.

In addition to climate-driven shifts in migration routes, latitudinal shifts in the spawning grounds of migratory cod in response to sea temperature change are known to have occurred in the twentieth century, for example, when Atlantic cod that originated in Iceland started spawning along the Greenland coast (Bonanomi et al., 2015). Such shifts may explain the significantly lower frequency of migratory cod in the local catch. Ólafsdóttir et al. (2014) showed lowered

Table 2. Overview of the number of regional references to Atlantic cod fishing in each century.

\begin{tabular}{lllll}
\hline \hline & Region & Bad & Average & Good \\
\hline Sixteenth century & North & 1 & 0 & 0 \\
& West & 0 & 0 & 0 \\
& South & 0 & 0 & 0 \\
Seventeenth century & North & 4 & 1 & 1 \\
& West & 6 & 2 & 28 \\
& South & 8 & 8 & 6 \\
Eighteenth century & North & 12 & 4 & 7 \\
& West & 5 & 15 & 14 \\
Nineteenth century & South & 8 & 6 & 23 \\
& North & 4 & 2 & 5 \\
& West & 2 & 4 & 19 \\
& South & 15 & 2 & 20 \\
\hline \hline
\end{tabular}

frequency of the $\operatorname{Pan} I^{B}$ allele, characteristic of migratory cod (Fevolden and Pogson, 1997; Pampoulie et al., 2006), in zooarchaeological Atlantic cod material from Iceland after AD 1550. The same study also reported lowered genetic diversity, which again supports fishing from a truncated Atlantic cod stock after AD 1550.

The current analysis identifies the proximity to rich fishing grounds as key to the development of the Icelandic commercial fisheries during the medieval period. The locations of fishing sites (Fig. 1) suggest that fishers targeted feeding and spawning migrations, and potentially spawning grounds, of Atlantic cod and that these sites provided the most consistently favorable fishing throughout the period. However,

Table 3. Results from the generalized linear model depicting estimates and significance of type of reference (good and bad vs. average) and geographical region (with an interaction term) and type of reference and century (with an interaction term). ${ }^{a}$

\begin{tabular}{lrlrc}
\hline \hline & Estimate & SE & \multicolumn{1}{c}{$t$ value } & $P$ value \\
\hline Intercept & -13.547 & 0.547 & -24.769 & $\mathbf{0 . 0 0 0}$ \\
Fourteenth century & 1.451 & 0.768 & 1.888 & 0.062 \\
Sixteenth century & -0.020 & 0.784 & -0.025 & 0.979 \\
Seventeenth century & -0.918 & 0.755 & -1.217 & 0.227 \\
Eighteenth century & -2.324 & 0.840 & -2.768 & $\mathbf{0 . 0 0 7}$ \\
Nineteenth century & -3.467 & 0.931 & -3.723 & $\mathbf{0 . 0 0 0}$ \\
\hline \hline
\end{tabular}

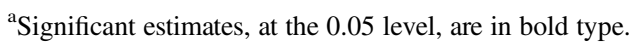


environmental change resulted in fisher movement on varying scales. Small-scale changes, such as coastal erosion destroying boat landings, forced fishermen to relocate to new sites, often in close proximity to earlier locations, which the archaeological record suggests occurred at different times in the northwest of Iceland (Edvardsson, 2010). On a larger scale, depletion of in-fjord fishing grounds forced many fisher-farmers to abandon their home bases and move to the larger commercial stations to fish (Magnússon and Vídalín, 1940). Large-scale changes, such as reoccurring lack of catch over long periods of time, forced fishermen to relocate nationally to fish seasonally, and from the late seventeenth century, fishermen from the north of Iceland traveled to the commercial fishing stations in the southwest (Kristjánsson, 1980; Pór, 2002). The current historical analysis shows that commercial fishing stations in North Iceland had been abandoned long before the eighteenth century and replaced by opportunistic subsistence fishing by local farmers. By the early eighteenth century, the number of boats and booths at commercial fishing stations in the Snæfellsnes peninsula and the Westfjords had dropped by $50 \%-60 \%$, and several sites had been abandoned (Fig. 1), but the abandonment of fishing sites was less pronounced in the south (Fig. 1). After the seventeenth-century collapse, the number of booths and boats does not begin to increase again until the early nineteenth century, and by the mid-nineteenth century, the number of booths exceeded their original number in most regions (Kristjansson, 1980). This is also reflected in the data set from Bjarnason (1883), which shows increased references to favorable fishing in the nineteenth century (Table 2).

Although the current multidisciplinary results support a significant role for climate-driven ecological shifts in a historical collapse of Atlantic cod fisheries in Iceland, the fisheries cannot be examined solely within an environmental context. The earliest written sources concerning European fishers in Icelandic waters date to the late fourteenth century (Íslenskir Annálar, 1847). From the period AD 1408 onward, the English sent large fishing fleets to Iceland annually. Other nations followed, primarily the Dutch, French, and Germans, and many European nations had fishing fleets in Icelandic waters by the late nineteenth century (Bjarnason, 1883; Porsteinsson, 1976, 1995; Simon-Thomas, 1935; Pálmadóttir, 1989; Jones, 2000; Starkey et al., 2000). Icelandic fishers frequently protested to local authorities about foreign fleets ruining fishing grounds and fishing gear (Bjarnason, 1883), suggesting that local fishermen attributed reduced Atlantic cod catches to the presence of European fishing fleets. The European fishing fleets may in fact have had the advantage of mobility, allowing them to respond to changing migrations and moving stocks, while the Icelandic fishing boats were limited to a fixed point (i.e., a fishing station) and had a limited sphere of operation. The Icelandic fishers had to risk the costly wait for the annual migrations, and when the migrating fish did not materialize in a particular area, fishers were forced to move to a new site. The relative certainty of the Atlantic cod catches around Iceland, procured during consistent annual spawning migrations, secured the early success of the land-based subarctic fisheries, but ultimately the local fisheries did not adapt sufficiently for Icelandic cod fisheries to flourish in a changing climate and an increasingly competitive environment. These results add to accumulating evidence for successful colonization and exploitation of subarctic environments in the Viking Age, followed by the creation of a flexible subsistence system (Simpson et al., 2001; Dugmore et al., 2007, 2012; McGovern et al., 2007), but then the eventual failure to adapt an established economy to technological and climate-driven changes.

To conclude, the current results show that lower sea temperatures in the North Atlantic coincided with lower lifetime ambient temperatures of Atlantic cod and lower frequency of migratory cod in the Icelandic Atlantic cod catches. These results support a shift in Atlantic cod migration routes or, more drastically, migratory cod spawning grounds. These ecological changes, perhaps in concert with increased international fishing pressure, appear to have resulted in a temporary collapse of Atlantic cod fisheries in Iceland, despite local fishers responding with increased mobility.

\section{ACKNOWLEDGMENTS}

We would like to acknowledge Tom McGovern for his conceptual input in developing this work and Ben Fitzhugh, David Orton, and James Barrett for useful comments on this article. We thank Leifur Pór Porvaldsson, Gylfi Björn Helgason, Zuhaitz Akizu, Marion Durand, Kjartan Ari Theoódórsson, Benedikt Kári Theódórsson, and Emma Lilja Ragnarsdóttir for field assistance and Einar Pétur Jónsson for his work on the otolith shape assignment.

\section{SUPPLEMENTARY MATERIAL}

To view supplementary material for this article, please visit https://doi.org/10.1017/qua.2018.147

\section{REFERENCES}

Amorosi, T., McGovern, T.H., Perdikaris, S., 1994. Bioarchaeology and cod fisheries: a new source of evidence. ICES Marine Science Symposia 198, 31-48.

Amundsen, C., Perdikaris, S., McGovern, T.H., Krivogorskaya, Y., Brown, M., Smiarowski, K., Storm, S., Modugno, S., Frik, M., Koczela, M., 2005. Fishing booths and fishing strategies in medieval Iceland: an archaeofauna from the of Akurvík, North-West Iceland. Environmental Archaeology 10, 141-198.

Árnason, E., Hernandez, U.B., Kristinsson, K., 2009. Intense habitat-specific fisheries-induced selection at the molecular Pan I locus predicts imminent collapse of a major cod fishery. PLoS ONE 4(5), e5529.

Astthorsson, O.S., Gislason, A., Jonsson, S., 2007. Climate variability and the Icelandic marine ecosystem. Deep Sea Research Part II: Topical Studies in Oceanography 54, 2456-2477.

Baasch, E., 1889. Die Islandfahrt der Deutschen, namentlich der Hamburger, vom 15. bis 17. Jahrhundert. Forschungen zur hamburgischen Handelsgeschichte 1, Hamburg.

Bardarson, H., McAdam, B.J., Thorsteinsson, V., Hjörleifsson, E., Marteinsdottir, G., 2017. Otolith shape differences between ecotypes of Icelandic cod (Gadus morhua) with known migratory 
behaviour inferred from data storage tags. Canadian Journal of Fisheries and Aquatic Sciences 74, 2122-2130.

Barrett, J.H., Locker, A.M., Roberts, C.M., 2004a. Dark Age economics revisited: the English fish bone evidence AD 600-1600. Antiquity 78, 618-636.

Barrett, J.H., Locker, A.M., Roberts, C.M., 2004b. The origins of intensive marine fishing in medieval Europe: the English evidence. Proceedings of the Royal Society of London B 271, 2417-2421.

Barrett, J.H., Orton, D., Johnstone, C., Harland, J., Van Neer, W., Ervynck, A., et al., 2001. Interpreting the expansion of sea fishing in medieval Europe using stable isotope analysis of archaeological cod bones. Journal of Archaeological Science 38, 1516-1524.

Bates, D., Mächler, M., Bolker, B., Walker, S., 2015. Fitting linear mixed-effects models using lme4. Journal of Statistical Software 67, 1-48.

Bjarnason, B., 1883. Um fiskveiðar íslendinga og útlendinga að fornu og nýju. Tímarit hins íslenzka bókmenntafélags. Reykjavík, pp. 166-242.

Bonanomi, S., Pellissier, L., Therkildsen, N.O., Hedeholm, R.B., Retzel, A., Meldrup, D., Olsen, S.M., et al., 2015. Archived DNA reveals fisheries and climate induced collapse of a major fishery. Scientific Reports 5, 15395.

Campana, S.E., 2005. Otolith science entering the 21 st century. Marine and Freshwater Research 56, 485-495.

Campana, S.E., Casselman, J.M., 1993. Stock discrimination using otolith shape analysis. Canadian Journal of Fisheries and Aquatic Sciences 50, 1062-1083.

Clark, C.T., Horstmann, L., Misarti, N., 2017. Quantifying variability in stable carbon and nitrogen isotope ratios within the skeletons of marine mammals of the suborder Caniformia. Journal of Archaeological Science: Reports 15, 393-400.

Dahl-Jensen, D., Mosegaard, K., Gundestrup, N., Clow, G.D., Johnsen, S.J., Hansen, A.W., Balling, N., 1998. Past temperatures directly from the Greenland Ice Sheet. Science 282, 268-271.

Disspain, M.C.F., 2016. Otoliths in archaeology: methods, application and future prospects. Journal of Archaeological Sciences: Reports 6, 623-632.

Drinkwater, K.F., 2005. The response of Atlantic cod (Gadus morhua) to future climate change. ICES Journal of Marine Science 62, 1327-1337.

Dugmore, A.J., Buckland, P.C. 1991. Tephrochronology and late Holocene soil erosion in South Iceland. In: Maizels, J.K., Caseldine, C. (Eds.), Environmental Change in Iceland Past and Present. Kluwer, Dordrecht, Netherlands, pp. 147-161.

Dugmore, A.J., Church, M.J., Buckland, P.C., Edwards, K.J., Lawson, I.T., McGovern, T.H., Panagiotakopulu, E., et al., 2005. The Norse Landnám on the North Atlantic Islands: an environmental impact assessment. Polar Record 41, 21-37.

Dugmore, A.J., Keller, C., McGovern, T.H., 2007. The Norse Greenland settlement: reflections on climate change, trade and the contrasting fates of human settlements in the Atlantic islands. Arctic Anthropology 44, 12-37.

Dugmore, A.J., McGovern, T.H., Vésteinsson, O., Arneborg, J., Streeter, R., Keller, C., 2012. Cultural adaptation, compounding vulnerabilities and conjunctures in Norse Greenland. Proceedings of the National Academy of Sciences USA 109, 3658-3663.

Edvardsson, R., 2010. The Role of Marine Resources in the Medieval Economy of Vestfirðir, Iceland. PhD thesis. Graduate Center, City University of New York, New York.
Edvardsson, R., 2018. Archaeological Excavation on the Island of Strákey in Strandir, Iceland in 2017, Excavation Report. Rannsóknasetur Háskóla Íslands á Vestfjörðum, Bolungarvík.

Emslie, S.D., Patterson, W.P., 2007. Abrupt recent shift in $\delta 13 \mathrm{C}$ and $\delta 15 \mathrm{~N}$ values in Adélie penguin eggshell in Antarctica. Proceedings of the National Academy of Sciences USA 104, 11666-11669.

Fevolden, S.E., Pogson, G.H., 1997. Genetic divergence at the synaptophysin (Syp I) locus among Norwegian coastal and north-east Arctic populations of Atlantic cod. Journal of Fish Biology 51, 895-908.

Fry, B., 1988. Food web structure on Georges Bank from stable C, $\mathrm{N}$, and $\mathrm{S}$ isotopic compositions. Limnology and Oceanography 33, 1182-1190.

Gardiner, M., 2016. The character of commercial fishing in Icelandic waters in the 15 th century. In: Barrett, J.H., Orton, D.C. (Eds.), Cod and Herring, The Archaeology and History of Medieval Sea Fishing. Oxbow Books, Oxford, UK, pp. 71-80.

Geffen, A.J., Høie, H., Folkvord, A., Hufthammer, A.K., Andersson, C., Ninnemann, U., Pedersen, R.B., Nedreaas, K., 2011. High-latitude climate variability and its effect on fisheries resources as revealed by fossil cod otoliths. ICES Journal of Marine Science 68, 1081-1089.

Gorokhova, E., 2017. Individual growth as a non-dietary determinant of the isotopic niche metrics. Methods in Ecology and Evolution 9, 269-277.

Hambrecht, G., Anderung, C., Brewington, S., Dugmore, A., Edvardsson, R., Feeley, F., Gibbons, K., et al., 2018. Archaeological Sites as Distributed Long-term Observing Networks of the Past (DONOP). Quaternary International (published online) http://dx.doi.org/10.1016/j.quaint.2018.04.016.

Harrison, R., 2014. The Siglunes Archaeofauna, I. Report of the Viking Age and Medieval Faunal Remains. NORSEC/HERC Zooarchaeology Laboratory Report No. 62. City University of New York, New York.

Heath, P., 1968. North Sea fishing in the fifteenth century: the Scarborough fleet. Northern History 3, 53-69.

Ingólfsson, A., 2006. The Intertidal Seashore of Iceland and Its Animal Communities. Zoological Museum, University of Copenhagen, Copenhagen.

Íslenskir Annálar sive Annales Islandici ab anno Christi 803 ad annum 1430, 1847. Copenhagen, p. 354.

Jakobsdóttir, K.B., Pardoe, H., Magnússon, Á., Björnsson, H., Pampoulie, C., Ruzzante, D.E., Marteinsdóttir, G., 2011. Historical changes in genotypic frequencies at the Pantophysin locus in Atlantic cod (Gadus morhua) in Icelandic waters: evidence of fisheries-induced selection? Evolutionary Applications 4, $562-573$.

Jiang, H., Eiríksson, J., Schulz, M., Knudsen, K.L., Seidenkrantz, M.S., 2005. Evidence for solar forcing of sea-surface temperature on the North Icelandic Shelf during the late Holocene. Geology 33, 73-76.

Jones, E.T., 2000. England's Icelandic fishery in the early modern period. In: Starkey, D. J., Reid, C., Ashcroft, N., (Eds.), England's Sea Fisheries. The Commercial Sea Fisheries of England and Wales since 1300. Chatham, London, pp. 105-110.

Jónsdóttir, I.G., Campana, S.E., Marteinsdottir, G., 2006. Otolith shape and temporal stability of spawning groups of Icelandic cod (Gadus morhua L.). ICES Journal of Marine Science 63, 1501-1512.

Kristjánsson, L., 1980. Íslenskir sjávarhœettir. Vol. 2. Menningarsjóður, Reykjavík. 
Leyden, J.J., Wassenaar, L.I., Hobson, K.A., Walker, E.G., 2006. Stable hydrogen isotopes of bison bone collagen as a proxy for Holocene climate on the Northern Great Plains. Palaeogeography, Palaeoclimatology, Palaeoecology 239, 87-99.

Libungan, L.A., Pálsson, S., 2015. ShapeR: an R package to study otolith shape variation among fish populations. PLOS ONE 10(3), e0121102.

Magnússon, Á., Vídalín, P., 1940. Jarðabók. Vol. I-VII. Hið Íslenska Fræðafélag, Copenhagen.

McGovern, T.H., Vésteinsson, O., Fririksson, A., Church, M.J., Lawson, I.T., Simpson, I.A., Einarsson, A., et al., 2007. Landscapes of settlement in northern Iceland: historical ecology of human impact and climate fluctuation on the millennial scale. American Anthropologist 109, 27-51.

Misarti, N., Finney, B., Maschner, H., Wooller, M.J., 2009. Changes in northeast Pacific marine ecosystems over the last 4500 years: evidence from stable isotope analysis of bone collagen from archeological middens. The Holocene 19, 1139-1151.

Neat, F.C., Wright, P.J., Zuur, A.F., Gibb, I.M., Gibb, F.M., Tulett, D., Righton, D.A., Turner, R.J., 2006. Residency and depth movements of a coastal group of Atlantic cod (Gadus morhua L.). Marine Biology 148, 643-654.

Ogilvie, A.E.J., Jónsdottir, I., 2000. Sea ice, climate and Icelandic fisheries in the eighteenth and nineteenth centuries. Arctic 53, 383-394.

Ogilvie, A.E.J., Jónsson, T., 2001. "Little Ice Age" research: a perspective from Iceland. In: Ogilvie, A.E.J., Jónsson, T. (Eds.), The Iceberg in the Mist: Northern Research in Pursuit of a "Little Ice Age." Kluwer Academic, Dordrecht, Netherlands, pp. 9-52.

Ólafsdóttir, R., Guðmundsson, H., 2002. Holocene land degradation and climatic change in northeastern Iceland. The Holocene 12, 159.

Ólafsdóttir, G.Á., Pétursdóttir, G., Bárðarson, H., Edvardsson, R., 2017. A millennium of north-east Atlantic cod juvenile growth trajectories inferred from archaeological otoliths. PLoS ONE 12 (10), e0187134.

Ólafsdóttir, G.Á., Westfall, K.M., Edvardsson, R., Pálsson, S., 2014. Historical DNA reveals the demographic history of Atlantic cod (Gadus morhua) in medieval and early modern Iceland. Proceedings of the Royal Society of London B 281, 20132976.

Orton, D.C., Makowiecki, D., de Roo, T., Johnstone, C., Harland, J., Jonsson, L., Heinrich, D., et al., 2011. Stable isotope evidence for late medieval (14th-15th C) origins of the eastern Baltic cod (Gadus morhua) fishery. PLoS One, 6(11), e27568.

Pálmadóttir, E., 1989. Fransí Biskví. Frönsku Íslandssjómennirnir. Almenna Bókafélagið, Reykjavík.

Pálsson, Ó.K., Thorsteinsson, V., 2003. Migration patterns, ambient temperature, and growth of Icelandic cod (Gadus morhua): evidence from storage tag data. Canadian Journal of Fisheries and Aquatic Sciences 60, 1409-1423.

Pampoulie, C., Ruzzante, D.E., Chosson, V., Jörundsdóttir, T.D., Taylor, L., Thorsteinsson, V., Daníelsdóttir, A.K., Marteinsdóttir, G., 2006. The genetic structure of Atlantic cod (Gadus morhua) around Iceland: insight from microsatellites, the Pan I locus, and tagging experiments. Canadian Journal of Fisheries and Aquatic Sciences 63, 2660-2674.

Patterson, W.P., Dietrich, K.A., Holmden, C., Andrews, J.T. 2010. Two millennia of North Atlantic seasonality and implications for Norse colonies. Proceedings of the National Academy of Sciences USA 107, 5306-5310.
Ramos, R., González-Solís, J., 2012. Trace me if you can: the use of intrinsic biogeochemical markers in marine top predators. Frontiers in Ecology and the Environment 10, 258-266.

R Core Team, 2017. R: A Language And Environment for Statistical Computing. R Foundation for Statistical Computing, Vienna, Austria.

Reibisch, J., 1899. Ueber die Eizahl bei Pleuronectes platessa und die Altersbestimmung dieser Form aus den Otolithen. Wissenschaftliche Meeresuntersuchungen (Kiel) 4, 233-248.

Robichaud, D., Rose, G.A., 2004. Migratory behaviour and range in Atlantic cod: inference from a century of tagging. Fish and Fisheries 5, 185-214.

RStudio Team (2015). RStudio: Integrated Development for $R$. RStudio, Boston, MA.

Simon-Thomas, M., 1935. Onze Ijslandsvaarders in de 17de en $18 d e$ Eeuw, Bijdrage tot de Geschidenis van de Nederlandsche Handel en Visscherrij. Amsterdam.

Simpson, I.A., Dugmore, A.J., Thomson, A.M., Vésteinsson, O., 2001. Crossing the thresholds: human ecology and historical patterns of landscape degradation. Catena 42, 175-192.

Sólmundsson, J., Jónsdóttir, I.G., Ragnarsson, S.Á., Björnsson, B., 2017. Connectivity among offshore feeding areas and nearshore spawning grounds; implications for management of migratory fish. ICES Journal of Marine Science 75, 148-157.

Star, B., Boessenkool, S., Gondek, A.T., Nikulina, E.A., Hufthammer, A.K., Pampoulie, C., Knutsen, H., et al., 2017. Ancient DNA reveals the Arctic origin of Viking Age cod from Haithabu, Germany. Proceedings of the National Academy of Sciences USA 114, 9152-9157.

Starkey, D. J., Reid, C., Ashcroft, N. (Eds.), 2000. England's Sea Fisheries: The Commercial Sea Fisheries of England and Wales since 1300. Chatham, London.

Stransky, C., Baumann, H., Fevolden, S.E., Harbitz, A., Høie, H., Nedreaas, K.H., Salberg, A.B., Skarstein, T.H., 2008. Separation of Norwegian coastal cod and Northeast Arctic cod by outer otolith shape analysis. Fisheries Research 90, 26-35.

Thorsteinsson, V., Pálsson, Ó.K., Tómasson, G.G., Jónsdóttir, I.G., Pampoulie, C., 2012. Consistency in the behaviour types of the Atlantic cod: repeatability, timing of migration and geo-location. Marine Ecology Progress Series 462, 251-260.

Valdimarsson, H., Astthorsson, O.S., Palsson, J., 2012. Hydrographic variability in Icelandic waters during recent decades and related changes in distribution of some fish species. ICES Journal of Marine Science 69, 816-825.

Van Neer, W., Ervynck, A., Bolle, L.J., Millner, R.S., Rijnsdorp, A.D., 2002. Fish otoliths and their relevance to archaeology: an analysis of medieval, post-medieval, and recent material of plaice, cod and haddock from the North Sea. Environmental Archaeology 7, 61-76.

Van Neer, W.V., Löugas, L., Rijnsdorp, A.D., 1999. Reconstructing age distribution, season of capture and growth rate of fish from archaeological sites based on otoliths and vertebrae. International Journal of Osteoarcaeology 9, 116-130.

Vésteinsson, O., 1998. Patterns of settlement in Iceland. A study in pre-history. Saga-Book of the Viking Society 25, 1-29.

Vésteinsson, O., 2000. The archaeology of Landnám Icelandic early settlement. In: Fitzhugh, W.W., Ward, E. (Eds.), Vikings: The North Atlantic Saga. Smithsonian Institution Press, Washington, DC, pp. 164-174.

Vésteinsson, O., 2016. Commercial fishing and the political economy of medieval Iceland. In: Barret, J.H., Orton, D.C. (Eds.), Cod and Herring, The Archaeology and History of Medieval Sea Fishing. Oxbow Books, Oxford, UK, pp. 71-80. 
Wurster, C.M., Patterson, W.P., 2003. Metabolic rate of late Holocene freshwater fish: evidence from $\delta^{13} \mathrm{C}$ values of otoliths. Paleobiology, 29, 492-505.

Wurster, C.M., Patterson, W.P., Stewart, D.J., Bowlby, J.N., Stewart, T.J., 2005. Thermal histories, stress, and metabolic rates of chinook salmon (Oncorhynchus tshawytscha) in Lake Ontario: evidence from intra-otolith stable isotope analyses. Canadian Journal of Fisheries and Aquatic Sciences 62, 700-713.
Pór, J.P., 2002. Saga sjávarútvegs á Íslandi. Sjósókn og sjávarfang. Árabáta og skútuöld. 1. Vol I. Bókaútgáfan Hólar, Reykjavík.

Pórarinsson, S., 1961. Uppblástur á Íslandi í ljósi öskulagarannsókna. Ársrit skógrektarfélags Íslands 1961, 17-54.

Porláksson, H., 1992. Vaðmál og verðlag. Vaðmál í utanlandsviðskiptum og búskap Íslendinga á 13. og 14. öld. PhD dissertation, University of Iceland, Reykjavík.

Porsteinsson, B., 1995. Enska öldin. Sögufélag, Reykjavík.

Porsteinsson, B., 1976. Tíu Porskastríð. Sögufélag, Reykjavík. 